\title{
Practical Aspects Regarding the Dissolution of a Company by Declaring the Company Null and Void
}

\author{
Andreea STOICAN \\ Bucharest University of Economic Studies, Bucharest, Romania \\ andreea.stoican@yahoo.co.uk
}

\begin{abstract}
Law no. 31/1990 on companies, in its initial form, developed a more traditional approach of the consequences of the non-compliance with the legal requirements for the establishment of a company. Though, in the mentioned version, the interest of protecting third parties prevailed, with the exclusion of the drastic sanction of nullity. However, the legislator, in time, reached the conclusion that a more modern approached needed to be taken into consideration, which should reach a balance between the need to protect the interests of third parties and the imperative to comply with the law with reference to the conditions that must be met to establish a company. Even so, in this current form of the regulation, a concern still remains, respectively that of trying to save the company, to bring it to fulfill the conditions of legality and, through this, to protect third parties also. But in some cases it is necessary for the company to cease to exist by declaring its nullity. Therefore, the current study aims in presenting and analyzing, from a more practical point of view, the occurrence of the nullity of a company and the consequences of such a measure both for the company itself and also for its partners.
\end{abstract}

Keywords: nullity, dissolution, breach of law, liquidation.

Law no. 31/1990 on companies, in its initial form, developed a more traditional approach of the consequences of the non-compliance with the legal requirements for the establishment of a company. Though, in the mentioned version, the interest of protecting third parties prevailed, with the exclusion of the drastic sanction of nullity. However, the legislator, in time, reached the conclusion that a more modern approached needed to be taken into consideration, which should reach a balance between the need to protect the interests of third parties and the imperative to comply with the law with reference to the conditions that must be met to establish a company.

Even so, in this current form of the regulation, a concern still remains, respectively that of trying to save the company, to bring it to fulfill the conditions of legality and, through this, to protect third parties also. But in some cases it is necessary for the company to cease to exist by declaring its nullity (Dumitru, 2017; Chirieac, 2019).

Article 227 paragraph 1 letter c) of Law no. 31/1990 stipulates that the company is also dissolved by declaring the company's nullity.

In this current regulation, the concern remains to save the company, to regularize it, to be brought within the parameters of legality and, through this, to protect third parties. But in some cases it is necessary for the company to cease to exist by declaring its nullity (Dumitru, 2017; Chirieac, 2019) .

As for the solution to be applied to the company established without complying with the rigors imposed by law, it differs depending on the date when the irregularity is found, before or after the registration of the company in the Trade Register. (Lefter, Dumitru, 2009)

Therefore, it is initially decided to regularize and, exceptionally, to pronounce the nullity of the company.

Through the current regulation, the legislator pursued three objectives, as following: firstly, to limit the causes of nullity; secondly, if there is, however, a ground for annulment, the limitation of a decision in the direction of the nullity of the company and thirdly, where the declaration of nullity 
has nevertheless taken place, as much as possible, the limitation of its effects (Judecătoria Oradea Civil Department, 2013).

As seen, for the situation in which a company was set-up without complying with the rigors imposed by law, the solution differs depending on the date when the irregularity is found, before or after the registration of the company in the Trade Register. That is why, as stated above, it is initially decided to regularize and, exceptionally, the nullity of the company will be pronounced.

For example, according to Decision no. 4369/2013 from the 27th of March 2013, pronounced by First Court of Oradea Civil Department, precisely for this reason, in the mentioned case, it was decided by the court of law that the situation must be regularized, recognizing that the company's location was correctly established by the articles of association, but not based on the lease contract initially submitted to the Trade Register, but based on the one signed by the company and another party, when they tried to change the headquarter.

As such, few aspects related to the regularization action need to be explained, in order to be able to understand the differences that exist between it and the action in annulment of the company.

Thus, if after the registration of the company in the Trade Register there are certain irregularities regarding its set-up, the law obliges the company's bodies to take the necessary measures to remove them. The term is of 8 days from the finding of irregularities (art. 48 from Law no. $31 / 1990)$.

If the company's bodies fail to fulfill this obligation within the legal term (art. 48 from Law no. 31/1990), any interested person may ask the court to oblige the company's bodies to fulfill the necessary measure for the regularization of the company. In order to ensure the execution of this legal requirement, the court may compel the administrators or censors to pay comminatory damages. As the law does not contain any limitation, it means that the regularization action can be used in case of notification of any incorrectness regarding the set-up of the company, regardless of its object.

The founders, the representatives of the company, as well as the first members of the management, administration and control bodies of the company are unlimited and jointly liable for the damage caused by the above-mentioned irregularities.

On the other hand, the non-compliance with some essential conditions regarding the set-up of a company may lead to the nullity of the company. Neither previously did the Commercial Code, nor Law no. 31/1990 initially, contained special provisions on the nullity of companies. Due to this reason, the common law regime of the nullity of legal acts was applied, in principle, also in the field of companies.

However, even in the absence of express provisions, it is important to be aware of the specificity of the company (Lefter, Dumitru, 2009), which, because it cannot be seen just as a contract, requires the mitigation of the effects arising from the cancellation of the company agreement.

But in the discussion regarding the nullity of a company, a difference must be made between the nullity of the company and the nullity of the articles of association or constitutive act, as it is also known.

However, part of the doctrine agreed that an independent existance of the nullity of the constitutive act needs to be excluded, as long as the valid existance of the company in the circumstance of the declaration of nullity of its constitutive act would be absurd to continue (Gheorghe, 2010). 
But, as regards the articles of association or constitutive act, which is usually a contract, the essential conditions for the validity of all contracts must be fulfilled. Therefore, in case of breach of such measures, the constitutive act will be null and void, according to the relevant legal provisions. The only situation in which the nullity of the constitutive act will also determine the nullity of the company occurs if it is a total nullity, therefore if it considers the constitutive act in its entirety. It is considered that such a breach identifies as a lack of the constitutive act (art. 56, Law no. 31/1990).

Other cases of nullity of contracts, such as, for example, the lack of capacity of the contracting parties or the vices of their consent will not affect the articles of association in its entirety, but only the legal relationship between the company and the incapable partner or whose consent was not genuine. For example, if the founders of the company did not have the necessary legal capacity as they were minors on the date of authentication of the constitutive act, but, at the moment of pronouncing the conclusion by the delegated judge, the incapacity had ceased, the irregularity was removed.

Even so, this situation of the lack of the constitutive act needs to be interpreted a bit different than literally. As the company must have and present the existance of a constitutive act at its setup in front of the Trade Register, without it, the submission being rejected, therefore considering the control system of the company's registration, it is practically impossible to deal with a lack in this respect. Rather, the provisions of the law need to be interpreted in the direction of an existance of a constitutive act, but affected by nullity in its entirety.

As far as the nullity of the company itself is concerned, it can only be pronounced by the court of law, not the associates or shareholders themselves. In a way, this need of pronouncing the nullity of a company by a higher authority is obvious, not only due to its importance, in the shade also of the intention of the legislator to first try to regularize the issues and only after that to pronounce the nullity of the company, but also in the idea that the only circumstance in which the nullity operates directly by law is when the company reaches its duration limit, which has no longer been extended (Lefter, Dumitru, 2011).

The object of the action for the nullity of a company is represented by the invalidation of the set-up of the company in the Trade Register, as the consequence of the non-observance of certain imperative requirements (Bratis, 2011).

The causes of nullity of a company are stated in article 56 from Law no. 31/1990 on companies and are the following: the constitutive act is missing or it was not concluded in authentic form; all the founders were, by law, incapable at the time of the incorporation of the company; the object of activity of the company is illicit, contrary to public order or morals; the conclusion of the delegated judge of registration of the company is missing; the legal administrative authorization to set up the company is missing; the articles of association do not provide for the name, object of activity or contributions of the shareholders or the subscribed share capital; the legal provisions regarding the minimum, subscribed and paid-up share capital were violated; the minimum number of shareholders provided by law was not fulfilled. This enumeration is limiting, not enunciative, and the enumerated situations are of strict interpretation, not being able to be extended (Decision no. 1984/2008 from the $5^{\text {th }}$ of June 2008, pronounced by the High Court Of Cassation and Justice, Second civil Department).

As such, in practice, it was considered that the only reason for nullity that can be circumscribed to the conditions provided by law, appears the one related to the minimum number of associates, from which, however, the provisions of article 283 paragraph 4 from Law no. $31 / 1990$ derogates in the sense that the companies with full or majority state capital can operate 
with any number of associates. Also, the fact that the company in dispute operated for a period of time without an National Regulatory Authority for Community Public Utilities Services' authorization does not lead to the declaration of the nullity of the company, but to other sanctions provided in the special legal provisions. The operating license cannot be confused with the administrative authorization to set up, in order to be invoked as a reason for the illegality of the decision of the previous decision of the court of appeal (Decision no. 2575/2009 from the $27^{\text {th }}$ of October 2009, pronounced by the High Court Of Cassation and Justice, Second civil Department).

However, the law does not provide the type of nullity for the above-mentioned situations, but, as they protect a public interest, it is considered to be an absolute nullity (Nemes, 2018).

Again, in order to try to save the company, the legislator provided in the law that the nullity cannot be declared if its cause, invoked in the application for annulment, was removed before the conclusions spoken in the court (art. 57, Law no. 31/1990).

As seen, the provisions of article 58 from Law no. 31/1990 state that the company declared null and void ceases to exist. On the other hand, those of article 227 consider the declaration of nullity a cause for dissolution. To a certain extent, we could say that the two articles not necessary contradict themselves, but are in diversity, as the dissolved company does not immediately cease to exist, but continues its existance with a limited legal capacity, that of the liquidation procedure (article 58 paragraph 2 from Law no. 31/1990).

As a consequence of the fact that the declaration of the nullity of the company produces effects only for the future, the associates will be liable for the social obligations. The declaration of the nullity of the company does not prejudice the acts concluded in its name and neither the company, nor the partners can oppose the nullity of the company to third parties of good-faith (Decision no. 1894/2010 from the $21^{\text {st }}$ of May 2010, pronounced by the High Court Of Cassation and Justice).

Because the validity of such acts remains, the associates who have unlimited and joint liability cannot invoke the nullity of the company in order to refrain themselves from executing their obligations towards such third parties (Dumitru, 2019).

As the law recognizes to any interested person both the right to request the regularization of the company and the right to request the declaration of nullity of the company, in practice it is possible that within one year from the registration of the company a conflict of interest will arise by initiating the two actions (Sandru, 2017). In such a circumstance, in absence of a legal provision, because of the intention of the legislator to correct the breach of the law at the set-up of a company, rather than end its existance, between the two actions, the regularization action should be successful and solved first. This is also the main interpretation in the matter given by the European Union's legislative acts, which, in this circumstance, the Romanian law transposed entirely and correctly. The regularization prooved itself to be mainly important not only from a legal point of view to have preference between the two actions, but also from an economic point of view (Lefter, Dumitru, 2009).

Therefore, as stated above, the nullity of the company is an exceptional sanction which occurs when the causes of nullity are not removed or when these causes cannot be removed.

In conclusion, as seen during the current study, it is important to understand, even though the law does not precisely state this, that the nullity of the constitutive act cannot entirely operate without the nullity of the company (Gheorghe, 2010). As such, the problem of the action in annulment of the constitutive act of the company was and still remains to be raised as the total efficiency of it is still put to question, if after obtaining the legal personality, the company has an independent existance, different than that of the constitutive act that was the basis of its legal set- 
up. Moreover, there can not be two nullities in such a situation, as only one of them, namely the nullity of the company itself, through its special character, absorbs the nullity of the constitutive act. That is why it is always essential to identify in which limit the nullity of the constitutive act also draws the special nullity of the company.

\section{References}

Bratiș Marian, Constituirea societății comerciale pe acțiuni, Hamangiu Publishing House, Bucharest, 2008

Chirieac Roxana, Societățile comerciale offshore - între optimizare și evaziune fiscală, Hamangiu Publishing House, București, 2019

Decision no. 4369/2013 from 27th of March 2013, pronounced by Judecătoria Oradea Civil Department, on https://legeaz.net/spete-civil-2/constatare-nulitate-contract-si-dizolvare4369-2013

Decision no. $1894 / 2010$ from the 21 st of May 2010, pronounced by the High Court Of Cassation and Justice, Commercial Department, on http://www.scj.ro/1093/Detaliijurisprudenta?customQuery \%5B0\%5D.Key=id\&customQuery $\% 5 B 0 \% 5 \mathrm{D}$. Value $=83086$

Decision no. 2575/2009 from the 27th of October 2009, pronounced by the High Court Of Cassation and Justice, Second civil Department, on http://www.scj.ro/1093/Detaliijurisprudenta?customQuery \%5B0\%5D.Key=id\&customQuery\%5B0\%5D. Value $=53232$

Decision no. 1984/2008 from the 5th of June 2008, pronounced by the High Court Of Cassation and Justice, Second civil Department, on http://www.scj.ro/1093/Detaliijurisprudenta? customQuery $\% 5 B 0 \% 5 \mathrm{D} . \mathrm{Key}=\mathrm{id} \&$ customQuery $\% 5 \mathrm{~B} 0 \% 5 \mathrm{D}$. Value $=83273$

Dumitru Ovidiu Ioan, Business Law. Lecture notes, Chapter 11. The formation of companies, ASE Publishing House, Bucharest, 2019

Dumitru Ovidiu Ioan, The European Company, Perspectives after Brexit, Tribuna Juridică, vol. 7, nr. 2, pg. $\quad 134-146, \quad 2017, \quad$ on http://www.tribunajuridica.eu/arhiva/An7v2/15.\%20Dumitru.pdf

Gheorghe Cristian, Nulităţi de drept comercial, CH Beck Publishing House, Bucharest, 2010

Law no. 31/1990 on companies, republished (r2) in the Official Monitor of Romania no. 1066 from the 17 th of November 2004

Leaua Crenguța, Societăţi comerciale. Proceduri speciale, CH Beck Publishing House, Bucharest, 2008

Lefter Cornelia, Dumitru Ovidiu Ioan, Dissolution of the Commercial Companies due to the Passing of Time Established as a Duration of the Company - Theoretical and Practical Aspects, Revista de Economie teoretică şi aplicată, no. 11 (564), pg. 59-66, 2011, on http://www.ectap.ro/dissolution-of-the-commercial-companiesdue-to-the-passing-of-timeestablishedas-a-duration-of-the-company-theoretical-and-practical-aspects-cornelialefter ovidiu-ioan-dumitru/a662/

Lefter Cornelia, Dumitru Ovidiu Ioan, Theoretical and Practical Aspects Regarding the Nullity of Commercial Company, Revista de Economie teoretică şi aplicată, nr. 11, 2009, p. 33-40, on http://www.ectap.ro/theoretical-and-practical-aspects-regarding-the-nulity-ofcommercial-companies-cornelia-lefter_ovidiu-ioan-dumitru/a422/, p.39

Lefter Cornelia, Dumitru Ovidiu Ioan, „,Theory and practice concerning the nullity of commercial companies", în volumul "Accounting and Management Information Systems - 4th International Conference AMIS 2009", the Faculty of Accounting and Management Information Systems, Academy of Economic Studies, Bucharest, Romania, ASE Publishing House

Lefter Cornelia, Dumitru Ovidiu Ioan, Reglementarea desfăşurării activităţilor economice de către persoane fizice autorizate, întreprinderi individuale şi întreprinderi familiale în baza Ordonanţei de urgenţă a Guvernului nr. 44/2008 - între noutate şi controversă, Revista Română de Drept Privat nr. 1/2009, Universul Juridic Publishing House, p. 104-116,

Nemeș Vasile, Drept comercial. Ediția a-III-a, Hamangiu Publishing House, Bucharest, 2018 
Șandru Daniel Mihail, Dreptul societăţilor în România, Universitară Publishing House, Bucharest, 2017.

PICBE | 1216 